International Journal of

Supply Chain

Management

(IJSCM)

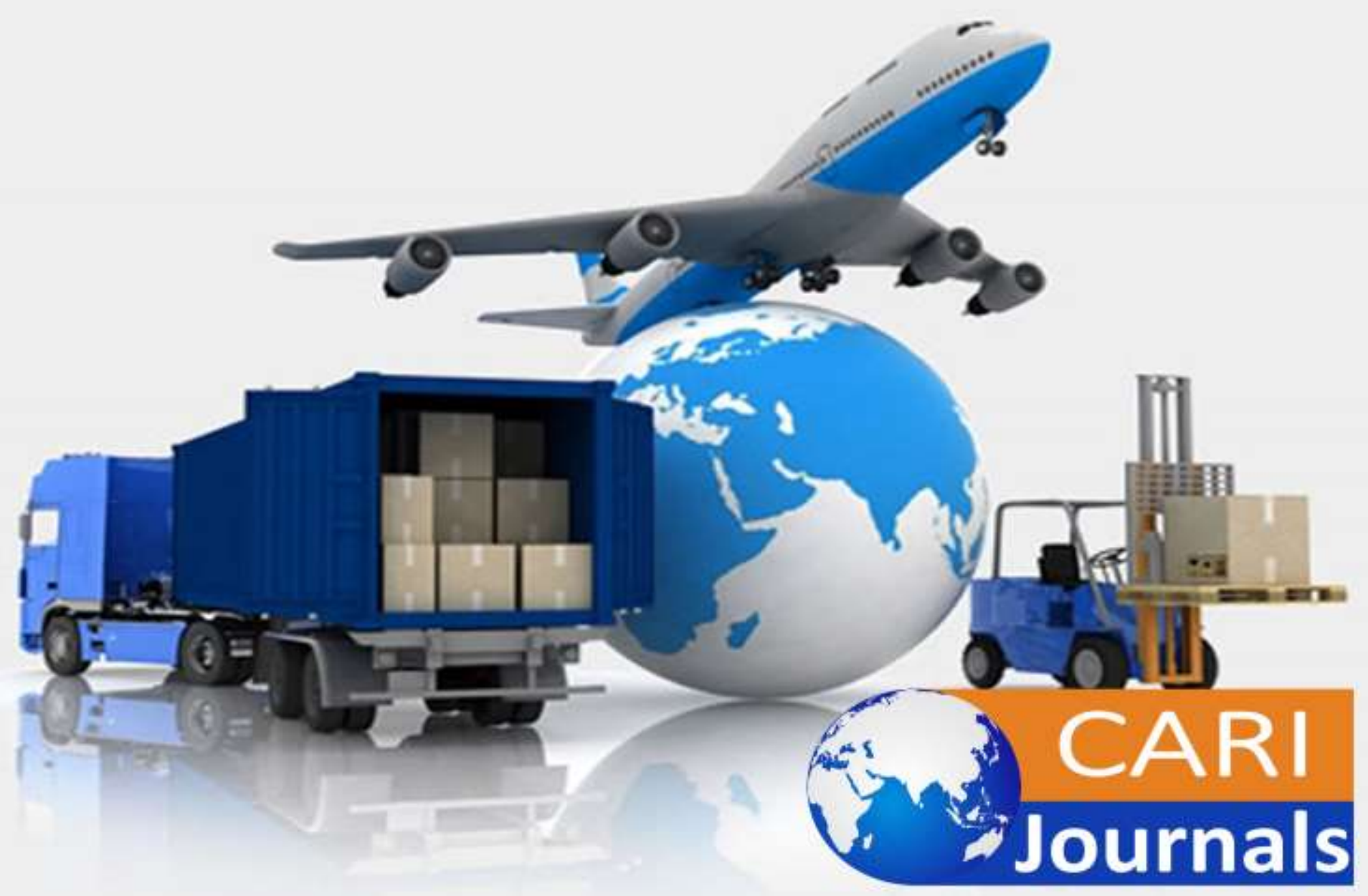




\title{
Supply Chain Management: A Game Changer in the Oil and Gas industry in Nigeria: A Review of Literature
}

Dr. Akintokunbo, Oluwarotimi Odunayo

Department of Management, Faculty of Management Sciences, Rivers State University, Nkpolu-

Oroworukwo, Port Harcourt, Nigeria

\author{
Arimie, Biebele Emmanuel \\ Department of Marketing (Supply Chain and Logistics Option), Faculty of Management Sciences, \\ Rivers State University, Nkpolu-Oroworukwo, Port Harcourt, Nigeria
}

\begin{abstract}
Nigeria has abundant deposit and supply of accessible crude oil and gas resources and it remains the mainstay of her economy. The oil and gas industry in Nigeria is a part of the global oil and gas market which depends on effective and efficient supply-chain management system for the seamless procurement of goods and services (domestic and international), logistics, operations and production management, warehousing, storage of goods from organisations supplier's suppliers to the customer's customers with the help of adequate use of modern information and communication technology. The purpose of this study was to examine supply chain management: a game changer in the oil and gas industry in Nigeria. The paper is largely a literature review, hence a desk research methodology was adopted. The paper revealed that the industry offers a classic model for changing the competition game in the sector through a lean, innovative and environmentally sustainable integrated supply chain management system, as today's competition is no longer between organizations, but among supply chains that compete to reduce their cost of acquisition, production, logistics and warehousing along the chain while delivering customers products and services of quality at the right time, quantity and quality, at the right place and total cost, and creating value throughout the chain.
\end{abstract}

Keywords: Supply Chain, Supply Chain Management, Oil and Gas Industry, Lean, Innovation, Environmental Sustainability and Game Changer.

\section{INTRODUCTION}

Every business venture, including the oil and gas industry can be likened to a game where strength, weaknesses, opportunities and threats can positively or negatively change the competitive advantage of one company against its competitors. The oil and gas industry deals with a global commodity which is highly volatile and very competitive. Consequently, weekly a new idea or publication is released by supply chain practitioners, professionals, consultants, academics, amongst others, presenting their opinions about supply chain management, its practices, impact 
and how companies are using it as a strategic management tool to gain competitive edge over one another. Often times, the opinions of the various researchers do not synchronize because they reflect the knowledge level, practice backgrounds and experiences of the people who assemble them. Generally, supply chains can be broken down into a network of "Tiers" depending on how the business owners design it to suit their operational needs. This is the essence of the network perspective theory in supply chain management, markets are viewed as a network of relationships among various entities, beginning with the supplier's-suppliers - the suppliers - the manufacturers/producers - the customers, and finally to the customer's-customers. Therefore, any change along the supply chain that fails to add value or creates wastage of resources will definitely affect all other integrated partners or partners in the network.

According to the Supply Chain Management Faculty of the University of Tennessee (2013), a game changer changes the way that things are done, thought about, or made. Consequently, Henry Ford was referred to as a game changer because of his revolutionary mass-production methods, this includes the world's first moving assembly line for cars, which made automobile ownership affordable for many middle-class Americans. For supply chain management, it is expected to be a leader in delivering economic profit to an organization seamlessly while satisfying the final customer and still make economic profit. Economic profit is important in every business because it means the company is delivering returns on investment rather than just improving services and making goods and services available to consumers. Supply chain managers are expected to be an engine of overall financial improvement for their companies as smart organisations are using innovations in their supply chain to generate cash to fund innovations in their goods and services streams for the growth of their business. Li, Ragu-Nathan, Ragu-Nathan and Subba, (2006), opined that today's competition is no longer between organizations, but among supply chains that compete to deliver customers products and services of quality at the right time while creating value all through the chain. In a bid to possess stronger competitive advantage and improve organizational performance in the game of oil and gas business, it is necessary now, more than ever, for an entity's supply chain to be managed more effectively and efficiently utilising supply chain management techniques and strategies like lean, innovation and environmental sustainability.

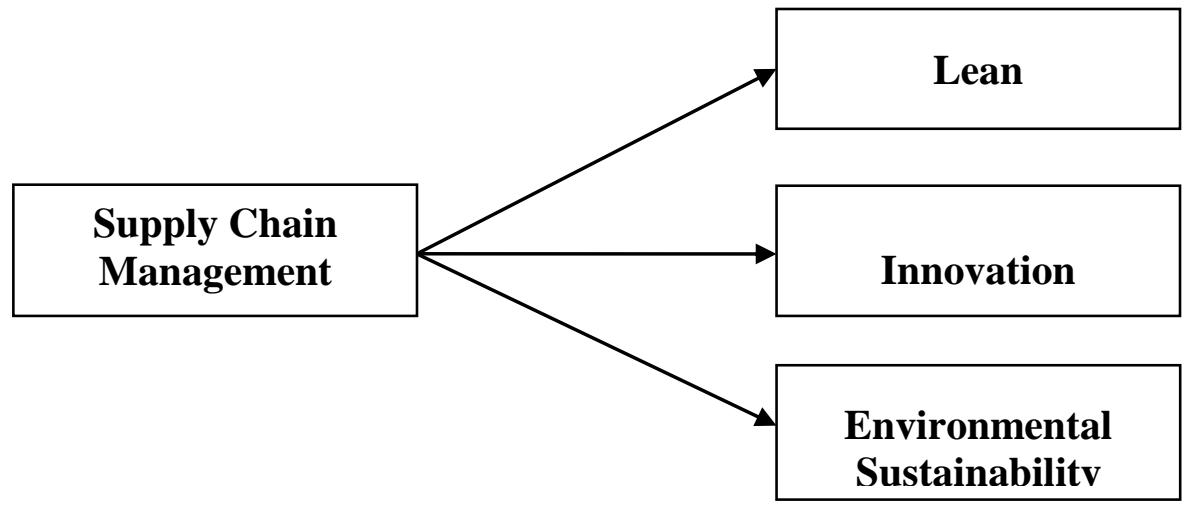

Fig. 1: Analysis of the link between Supply Chain Management and Game Changers Source: Akintokunbo \& Arimie from review of literature (2021) 
International Journal of Supply Chain and Logistics

ISSN 2520-3983 (Online)

Vol. 5, Issue No.3, pp 54 - 68, 2021

www.carijournals.org

\section{LITERATURE REVIEW}

\section{The Concept of Supply Chain Management}

A lot of definitions of supply chain includes words like; integration, connectivity, information exchange, seamless, communication, linkages, logistics, etc. However, Plenert (2007), opined that supply chain is in general known to be related to the flow of goods, information and funds between different entities, and it is often called a value chain, because all the stages that do not add value to the chain must be eliminated.

It is a statement of fact that there is no universally accepted definition of the concept of supply chain management; hence for $\mathrm{Li}$, et al (2006), the concept can be looked at from two perspectives, namely; purchasing and supply management perspective, and transportation and logistics management perspective. The purchasing and supply management perspective defines it as the integration of supply base that evolved from the traditional purchasing and materials functions, while the transportation and logistics management perspective, sees it as being synonymous with integrated logistics systems, and thus focuses on inventory reduction both within and across organizations in the supply chain. In our view, supply chain management may be described as the management of entities directly linked in the upstream, mid-stream and downstream flow of funds, information, and communication, use of technology and relationship management within a global, national or local environment with processes managed by people; from a supplier's supplier, production, to a customer's customer. Therefore, it is a critical nerve center to achieving competitive advantage in any business value chain including that of companies in the oil and gas sector of the economy, as it involves integrating and optimizing supply chain to maximize speed, flexibility, effectiveness, efficiency and economy. In the oil and gas industry the supply chain of a company is usually linked to its upstream suppliers through the procurement function, then to the midstream which deals with the transportation, refining and storage of the refined products, while the downstream is linked to customers through the marketing function as materials, information, finance, etc flow through the supply-chain with the aid of technology and its attendant negative impacts on the environment, particularly at the exploration and production phases and the refining stage too.

For Fawcett, Ellram and Ogden (2007), supply chain management is the design and management of seamless, value adding processes across organizational boundaries through the integration of people and technological resources to meet the real needs of the end customer. On his part, Webster (2008) described supply chain as two or more parties linked by a flow of resources typically, materials, information and money, and went further to state that supply chain management involves the management of activities surrounding the flow of raw materials to finished products or services enjoyed by end customers, and back, in the case of recycling or returns. 
International Journal of Supply Chain and Logistics

ISSN 2520-3983 (Online)

Vol. 5, Issue No.3, pp 54 - 68, 2021

WWW.carijournals.org

\section{The Concept of Game Changer}

The concept of game changer according to Business Dictionary (n.d), is a person or idea that transforms the rules, processes, strategies and management of business functions. Within the context of business, supply chain management has revolutionized how businesses compete against one another and any company that cannot build an effective and efficient supply chain system and implement same successfully cannot survive the present level of intense competition which is global in nature.

There are many measures of performance in the oil and gas supply chain management including profitability, market share, customer satisfaction, customer experience, service quality, amongst others, the performance measures of supply chain management as a game changer used in this paper for the purpose of this work are as follows: (1) Lean, (2) Innovation, and (3) Environmental Sustainability.

\section{Lean}

The core concept of lean thinking is derived from the Japanese term muda, described by Womack, Jones and Roos (1990), in their book, "Machines that changed the World". Muda in Japanese means waste or any human activity that absorbs resources but creates no value. These wastes include but not limited to spoilt products, unnecessary processing steps, the aimless movement(s) of personnel and goods, idle time during shutdowns or because of lack of materials, uneconomic or needless stocking of goods (raw materials, semi-finished and finished goods) and services that fail to meet customers' requirements.

The increasing customers' demands for high quality petroleum products and other alternative sources of energy with more flexibility and at a lower cost of production and distribution have generated a new trend in the global oil industry competitiveness. Therefore, lean production as a systematic method for the elimination of waste within a production and processing system, takes into consideration waste generated through overload and waste produced through inequality in workloads. Lean production refers to a business model that emphasizes on meeting customers' expectations by delivering quality products at the least cost when required.

Oil companies in Nigeria can gain competitive advantage from lean production practices; as such practices will enable the organizations to get superior performance through reduction of wastes and other related costs (Ohno, 2008). Uzochukwu and Ossai (2016), suggests that most organizations pursue lean production in response to their need to fundamentally improve business competitiveness by reducing costs while increasing quality and customer responsiveness including meeting delivery time. They further posited that lean production techniques provide one of the most significant methods to improve overall business performance in the upstream and downstream oil and gas business. These techniques are applicable to drilling/completion operations, production/maintenance, operations and facilities construction as well as the contractors for drilling, service providers and facilities construction companies that support the operations of the oil and gas organisation. 
International Journal of Supply Chain and Logistics

ISSN 2520-3983 (Online)

Vol. 5, Issue No.3, pp 54 - 68, 2021

WWW.carijournals.org

The proper planning and implementation of lean production system can lead to reduction in: production cost, waste, time and the use of labour and materials, while increasing customer service levels and satisfaction. It will also improve quality, increase organizational profit and set the organization on the part of continuous improvement.

According to Lean Enterprise Institute (2009) the term lean was coined by Krafcik in the late 1980's. The philosophy was brought to the attention of the Western world within the same period because of the competitiveness of the Japanese automobile industry which offered quality products at lower prices, since defining the word lean is somehow difficult, it is likely that every company exercising lean thinking will follow their own unique course (Lewis, 2000). It is the process of removing all of the wasted time and resources in the production process. For Mark, Wilson and Ram (2009), lean can be considered as a value, a philosophy, a management concept, a work culture, a technique, a methodology or an ethos. However, today, lean is evolving into a management approach that improves all the processes at each level of an organization (Womack, Jones \& Roos, 1990; Liker, 1998).

According to Bhasin and Butcher (2006), some of the common lean procurement methodologies in a supply chain are; Kaizen, Kanban systems and Supplier development. A long term philosophy, processes, people and right culture are essential to convert an organization into a lean enterprise (Liker, 2004; Henderson \& Larco 1999). Long term relationships with suppliers are important elements of lean supply (Kabuga, 2012). Kabuga (2012) further posits that today's demand driven supply chains require lean procurement methods whose goals are: to eliminate waste in all procurement cycles, prevent shortages, reduce inventory investment, reduce procurement lead time and cost, increase inventory turnover and ensure customers' satisfaction, as these methods ensure greater efficiency and standardization of procedures. Thus, applying lean methods to procurement function and purchasing activities can dramatically increase a company's performance and profits.

Companies may fail to effectively implement lean procurement methods due to lack of system thinking (Sohal and Eggleston, 1994). Employees may not be willing to adapt to new methods and may exhibit resistance to change. The organization may as well lack the internal capabilities to facilitate education and training, lack of clear responsibility in the supply chain, lack of management and suppliers' engagement, insufficient, planning monitoring and control may also inhibit the effective implementation of lean procurement. Lack of clarity over the supply chain and the struggle to localize and differentiate value from waste may hinder effective implementation of lean procurement methods in a supply chain.

The lean approach consists of various practices which aim to improve efficiency, quality and responsiveness to customers. Womack et al (2009) pointed out that all activities and processes associated with leanness attempt to achieve three basic objectives namely; flow, pull and strive for excellence. Flow deals with the movement of inventory through a supply chain continuously with minimal queues. Pull deals with customer order triggered operations and pulling materials through the supply chain rather than having schedules for upstream activities driving the rate of procurement. Strive for excellence ensures that supply chains operations are efficient all wastes are identified and removed. 
However, the primary objective of lean can be said to be synonymous with that of supply chain management as they both seek to get the right materials and or services, to the right place, at the right time, in the right quantity, from the right source and at the right price/cost, while minimizing waste, be responsive and open to change. The above objectives are to be executed by the organizations employees and supply chain partners who make the products and render the services, and so own the processes.

\section{Innovation}

A supply chain stands for a network of businesses that are associated to transform basic materials into finished goods and services and to supply same to end customers (Johnson, 2010). Literally it must be managed in the most streamlined and cost-effective way possible. Competitive pressures as well as rough business scenario thrust companies towards innovation. Innovation is essential for firms to react to fast changes in products and services along with customer's demand and issues (Kim \& Rhee, 2012). Innovation happens within processes, technologies, services, strategies and organisational structures are carefully thought through, planned and modeled. Today, supply chain innovation is conceptualized as a collection of enterprise-wide initiatives consisting of research and development, technological investments, process optimization, introduction of new products and services, building new models, knowledge acquisition and management through education and training, cross functional engagement, across nations and across-sectors for partnerships, market intelligence, and other activities. The aim of these activities goes beyond facilitating the accomplishment of better supply chain efficiencies and effectiveness to improving the overall firm performance (Moreira, Ferreira \& Zimmermann 2018; Mandal 2016).

Alicke, Hoberg and Rachor (2018), say Supply Chain innovations are becoming game changers. They stated that the concept of "Supply Chain 4.0" or "digital supply chain" enables supply chain managers to see the full value chain which includes suppliers and the origins of materials/services needed for various forms of smart production, end to end digital supply chain and the final destination, regardless of the number of intermediaries, steps and players. Supply chain innovations in technology is growing very fast as many companies are keying into new technology possibilities that are available and are testing same within their organizations. These organizations have been advancing their digital supply chain revolutions and they are getting significant results on service delivery, costs reduction, release of tied down capital, agility, and customer experience.

Researchers agree that supply chain innovation aid companies to support their competitive position and move supply chain performance forward (Flint \& Larsson, 2007). Innovation in supply chain is accepted to make strides in operational effectiveness and upgrade service viability (Arlbjørn, de Haas \& Munksgaard, 2011). Specifically, supply chain innovation includes technologically improving processes and strategies within the outbound supply chain as well as changes in product, process or service that either upgrades productivity or move forward final customer's satisfaction (Seo \& Mason 2015). 
Sunil (2019), conclude that innovative supply chains facilitate flexible sourcing, manufacturing and distribution as a critical antecedent of fast response to dynamic customer requirements. Supply chain agility is a firm's capability to work together with its suppliers, distributors and customers to rapidly respond, recover or adapt to changes in the market and other disruptions. Supply chain innovation builds the agility and resilience required to make the supply chain function optimal at all times.

Evangelista, McKinnon \& Sweeney (2012), in their opinion stated that supply chain innovation promotes sustainability in cost savings, revenue generation, customer satisfaction, and strategic partnerships. Smooth supply chains contribute to the sustained competitive position of an organization, especially because of greater levels of customer satisfaction. For Moreira, et al, (2018), quality and process enhancements reduce the incidence of product damages and waste, which leads to minimized customer complaints and environmental pollution

\section{Environmental Sustainability}

Environmental sustainability is what many sustainability advocates has historically focused on (Wheeler, 2004). Environmental issues have been the leading focus of research over the past 20 year (Carter and Easton, 2011) and it is now of global concern to many individuals who are mounting pressure on companies to become more environmentally responsible in their processes, raw materials extraction and production methods. The environment is a key component of sustainability and has been at the forefront globally as it relates to climate change, global warming and rising energy prices. As a result of the above, the terms sustainability and environment are interchangeably being used by researchers and managers (Carter and Easton, 2011).

Environmental sustainability relates to preserving natural resources such as minerals and the atmosphere amongst others, in the absence of which man cannot exist (Yusuf, Angappa, Ahmed, Mohammed, Nagham and Shuang \& 2012). Environmental sustainability is the protection of sources of raw materials needed to satisfy human needs, for this reason, man should not create more waste than the environment can accommodate, and human consumption is beginning to recognise and emphasise sustainability. Flowing from the above, environmental sustainability can be seen as a set of constraints on the four major activities regulating the scale of the human economic subsystem namely; the use of renewable and non-renewable resources on the source side, and pollution and waste assimilation on the sink side (Goodland, 1995). Put differently, Redclift (1987), stated that environment is both the supplier of inputs and a sink of wastes. On the sinks side, there is the need of 'holding wastes emissions within the assimilative capacity of the environment without impairing it. On the source side, harvest rates of renewables' must be kept within regeneration rates' (Goodland, 1995).

Carter and Rogers (2008), declared that Sustainable Supply Chain Management represents the systemic integration of critical business processes which enables companies and their supply chains to fulfill economic, environmental and social goals, as such companies are able to reach short term economic goals and become proactive in addressing their supply chain activities long term environmental and social expectations. Furthermore, close cooperation of oil and gas supply chain management, particularly with suppliers, improve the environmental performance of logistics operations. 
Madu (1996), say an organization that excels on environmental protections is not only doing it to gain societal acceptance but is also applying a business strategy that produce enormous profits. Therefore, supply chain management innovations through technologies developed, are changing the oil and gas industry business game by preserving the environment while facilitating the ability to continuously improve our quality of life. 
Oil and Gas Supply Chain Management model

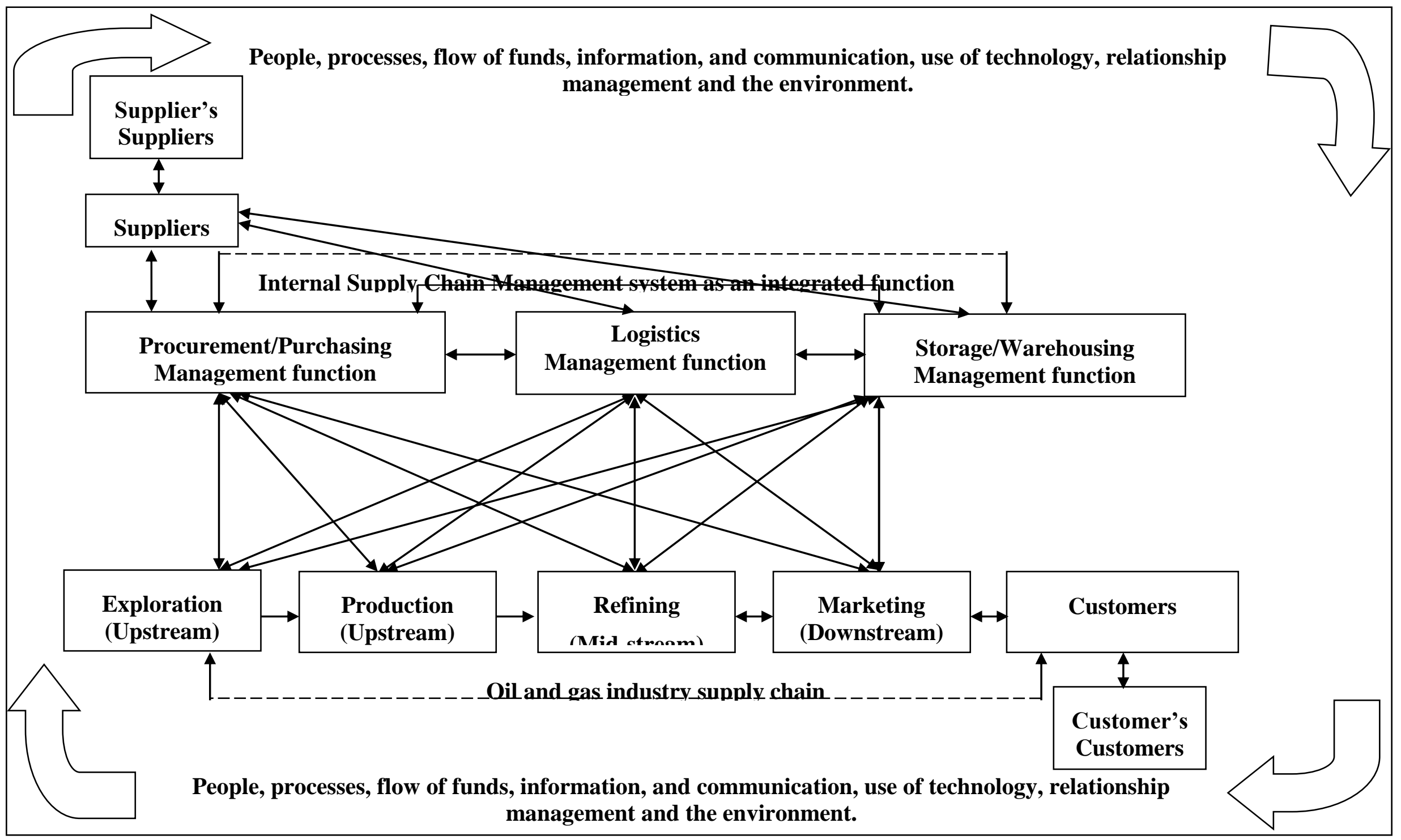

Fig 2: Oil and Gas Integrated Supply Chain Management conceptual framework. Source: Desk Research, Akintokunbo \& Arimie (2021) 
International Journal of Supply Chain and Logistics

ISSN 2520-3983 (Online)

Vol. 5, Issue No.3, pp 54 - 68, 2021

www.carijournals.org

\section{Oil and gas industry supply chain flow process (Upstream - Midstream - Downstream -}

\section{Customer/Consumer).}

The oil and gas industry is mainly divided into three components or parts namely:

Upstream: The upstream component focuses on exploration and production of crude oil and gas. While the exploration phase deals with the search by geologists and geophysicists to find oil and or natural gas in commercial quantities to break-even and make profit for the investors (companies), the production phase of the upstream starts when the company is through with exploration. The production phase deals with drilling and extracting the hydrocarbons from the ground, and separating the mixture of natural gas, crude oil, water, solids, and removing all impurities from the commercial gas and crude oil for storage in very large storage facilities like terminals, tanks Floating, Production, Storage and Offloading (FPSO) and Floating, Storage and Offloading (FSO) facilities in the case of deep offshore exploration.

Midstream: The transportation, storage and refining process is the midstream component in the oil and gas industry supply chain. It is the link that receives the outputs (crude oil and gas) from the various Upstream production facilities/sites through pipelines to oil tankers of various sizes, barges, etc for companies with crude term Contracts and Direct Sale/Direct Purchase (DSDP) agreements as Off-Takers of crude oil from Nigeria and distills/refines the crude oil into sellable products like petrol, kerosene, diesel, jet fuel, liquefied petroleum gases (LPG), bio fuel, etc, and from where the refined products find their way to the bulk buyers/wholesalers and some retailers in the downstream who are owners of tank farms and other major storage facilities.

Downstream: The downstream part of the oil and gas supply chain business that is made up of bulk buyers/wholesalers, including the DSDP agreement holders and some retailers who are focused on delivering the refined products within Nigeria and from abroad, to other major marketers/retailers and or filling/gas stations, who in turn supply petroleum products to Nigeria National Petroleum Corporation or sells to other middlemen as retailers and from there to other customers and then the consumer's-customer/final end-users as companies and individuals, whose use affects the environment, including the soil from where it was originally extracted from as a raw material in the form of crude oil and gas.

\section{Internal Supply Chain Management system as an integrated function (Procurement/Purchasing,}

\section{Logistics, Warehousing/Storage, Operations and Marketing)}

The internal supply chain management system in the oil and gas industry is an integration of three formerly distinct management functions to form one internal integrated management function called supply chain management which denotes the general coordination of activities that involves procurement, purchasing, stores, warehousing, logistics, materials and supply management (Chartered Institute of Purchasing and Supply Management of Nigeria, 2007). The integrated functions are have been categorized generally as follows; Procurement/Purchasing, Logistics, Warehousing/Storage. 
Procurement/Purchasing: within the context of civility, commerce and economics; this component of the supply chain is a planned, strategic and professional business process of acquiring of all kinds of goods, services and works in exchange for a monetary or equivalent payment or consideration; by means of lease/hire, hire purchase or outright purchase, to achieve the strategic objective of the company. It is this function that deals directly with the suppliers for all the inputs the companies require to deliver their operations successfully. These suppliers also some times, rely on their own suppliers who may be the producers of raw materials or the manufacturers of some goods, equipment and consumable. Hence they are referred to here as supplier's-suppliers.

Logistics: This is that component of the supply chain process that plans, implements, and controls the efficient, effective flow (forward and reverse) of raw materials, work-in-progress inventory, finished goods, services and related information from the point-of-origin to the point-of-consumption with the objective of satisfying the internal and external customers in a cost-effectively manner, while ensuring that current and future profitability are maximised.

Storage/Warehousing: Warehousing is that component of the supply chain that stores and keep records of goods (raw materials, parts, goods-in-process, finished goods, etc) at and between point of origin and point of consumption, and provide information to management on the status, condition, and disposition of the things in stock, and ensuring that all the materials within their warehouse, store, tank farms or stock yard are secured and are in good condition always.

\section{The oil and gas industry supply chain flow process and internal supply chain management}

\section{system as an integrated function}

The internal supply chain management system as an integrated function in any oil and gas company generally coordinates the Procurement/Purchasing, Logistics, Warehousing/Storage, Operations and Marketing activities as one seamless function in the oil and gas industry supply chain flow process which is segmented into Upstream, Midstream and Downstream operations. Procurement/Purchasing, Logistics, Warehousing/Storage, Operations and Marketing activities are carried out at the exploration/production state within a particular organization. Same thing happens at the midstream and downstream distinctly at the individual company levels. In all the activities and operations in the oil and gas supply chain and the individual company's supply chain management function; people and processes are involved at every stage; funds and information are also flowing; people are communicating and relationships are being built and management for effective, efficient and sustainable operations with a lot of impact on the environment. People, processes, flow of funds, information, and communication, use of technology and relationship management all interact and the environment receives the outputs and outcomes.

\section{CONCLUSION}


A combination of lean, innovations and environmental sustainability has fundamentally changed the way supply chains operate and even have the potentials of affecting global economies. However, it is already clear today that most supply chains by the year 2025 will differ significantly from those of 2021, as they will continue to improve on their performances and become more efficient, more customized, faster and safer in operations, and will provide a much better customer experience as supply chain management is a strong contributor to companies' performance in the oil and gas industry, cross-functionally and across the entire linkages of the chain with improved excellence in cost reduction of operations, improved service delivery to customers and not compromising but protecting the environment for the future generations to come.

\section{RECOMMENDATION}

As a result of the foregoing, this paper recommends that oil and gas companies should harness the maximum benefits of lean thinking, innovations and environmental sustainability in their oil and gas supply chain management system to change the game to their advantage, and achieve greater effectiveness and efficiency. It is also recommended that firms adopt the oil and gas supply chain management model in figure 2 for more supply chain integration and visibility.

\section{REFERENCES}

Alicke, K, Hoberg, K, \& Rachor, J (2018). Supply Chain 4.0 innovations are becoming game changers. Retrieved from: https://www.researchgate.net/publication/334508101. Retrieved on the 16th of August 2021.

Arlbjørn, J. S., de Haas, H., \& Munksgaard, K. B. (2011). Exploring supply chain innovation. Logistics research, 3(1), 3-18.

Azevedo. (2013). Ecosilient Index to assess the greenness and resilience of the upstream automotive supply chain. Journal of Cleaner Production, 56, 131-146.

Bhasin, S., \& Burcher, P. (2006). Lean viewed as a philosophy. Journal of Manufacturing Technology Management.

Carter, C., R. \& Easton, P. L. (2011). Sustainable Supply Chain Management: Evolution and Future Directions. International Journal of Physical Distribution and Logistics Management, VOL. 41 (1): 46-62

Carter, C., R. \& Rogers, D., S. (2008). A framework of sustainable supply chain management: Moving toward new theory. International Journal of Physical Distribution and Logistics Management, 38, 360-387.

Chartered Institute of Purchasing and Supply Management of Nigeria (Establishment) Act, 2007.

Evangelista, P., McKinnon, A., and Sweeney, E. (2012). Supply Chain Innovation for Competing in Highly Dynamic Markets: Challenges and Solutions. Business Science Reference, IGI Global, Hershey PA, USA. 
International Journal of Supply Chain and Logistics

ISSN 2520-3983 (Online)

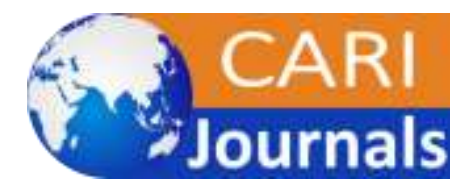

Vol. 5, Issue No.3, pp 54 - 68, 2021

WWW.carijournals.org

Evans, M., (2020). What is environmental sustainability? Retrieved from https://www.thebalancesmb.com/what-is-environmental-sustainability-3157876/. Retrieved on the 18th of August 2021.

Fawcett, S., E., Ellram, L. M., \& Ogden, J. A. (2007). Supply chain management: from Vision to Implementation. New Jersey: Pearson Prentice Hall.

Flint, D. J., \& Larsson, E. (2007). Supply chain innovation. Handbook of Global Supply Chain Management, Sage, Thousand Oaks, CA, 475-488.

Goodland, R. (1995). The Concept of Environmental Sustainability. Annual Review Ecological System, 26, 1-24

Henderson, B., A. \& Larco, J., L. (1999). Lean transformation: how to change your business into lean enterprise. Virginia: Oaklea Press.

Johnson, M. (2010). Barriers to innovation adoption: a study of e-markets. Industrial Management \& Data Systems, 110 (2), 157-174.

Kabuga, M. W. (2012). Lean procurement methodologies used by large scale manufacturing firms in Nairobi, Kenya. A research project submitted in partial fulfillment of the requirement for the award of master of business administration (MBA), school of business, university of Nairobi.

Kim, J., \& Rhee, J. (2012). An empirical study on the impact of critical success factors on the balanced scorecard performance in Korean green supply chain management enterprises. International Journal of Production Research, 50(9), 2465-2483.

Lean Enterprise Institute, 2009. What is Lean. Retrieved January 21, 2011, from https://www.lean.org/whatslean/ . Retrieved on the 18th of August 2021.

Lee., J., \& Tai, S., W. (2008). Environmental Management and Sustainable Development in the Oil and Gas Industry. Netherlands: CRC Press/Balkema.

Lewis, M. (2000). Lean production and sustainable competitive advantage. International journal of operations \& production management, 20(6), 959-976.

Li, S., Ragu-Nathan, B., Ragu-Nathan, T., \& Subba, R., S. (2006). The impact of supply chain management practices on competitive advantage and organizational performance. Omega. $34(2), 107-124$

Liker, J., K. (1998). Becoming lean: Inside stories of US Manufacturers. Productivity press, New York, NY.

Liker, J., K. (2004). The Toyota way: 14 management principles from the world's.

Madu, C. N. (1996). Managing green technologies for global competitiveness. ABC-Clio, LLC, Florida.

Mandal S. (2016). An empirical competence-capability model of supply chain innovation. Bus Theory Practice. 17: 138-149. 
International Journal of Supply Chain and Logistics

ISSN 2520-3983 (Online)

Vol. 5, Issue No.3, pp 54 - 68, 2021

www.carijournals.org

Mark, Wilson \& Ram (2009). Enabling lean procurement: a consolidation model for small- and medium-sized enterprises. Journal of Manufacturing Technology Management, 20 (6), 817833.

Moreira A, C., Ferreira L. D., \& Zimmermann R, A. (2018). Innovation and Supply Chain Management: Relationship, Collaboration and Strategies. Springer.

Ohno, T. (2008). Portland: Workplace Management. Productivity Press.

Osterwalder, A., \& Pigneur, Y. (2010). Business model generation: a handbook for visionaries, game changers, and challengers. John Wiley \& Sons.

Plenert, G. J. (2007). Reinventing lean: Introducing lean management into supply chain. Burlington, mass: Butterworth-Heinemann.

Redclift, M. (1987). Sustainable development exploring the contradictions. London: Rutledge.

Seo, Y. J., \& Mason, R. (2015). Supply chain innovation and risk management capability: their relationships and impacts on competitive advantage. In NOFOMA Conference.

Sohal, A. S., \& Egglestone, A. (1994). Lean production: Experience among Australian Technology Management, $17(1,2), 56-72$.

Sunil K (2019). Supply Chain Innovation: The Core Capabilities Required and Expected Outcomes. Journal of Information Technology \& Software Engineering. 9:256. doi:10.35248/21657866.19.9.256

United Nations Development Program (UNDP) in Kazakhstan (2004). Environment and Development Nexus in Kazakhstan. Publication series \#UNDPKAZ 06. Almaty, Kazakhstan.

University of Tennessee Supply Chain Management Faculty (2013). Game changing trends in supply chain. First annual report by the Supply Chain Management Faculty of the University of Tennessee. University of Tennessee global supply chain institute, Knoxville.

Uzochukwu, O., C., and Ossai, I., F. (2016). Lean production: A frontier for improving performance of oil and gas companies in Nigeria. Pyrex Journal of Business and Finance Management Research, 2(5), 35-41

Webster, S. (2008). Principles and tools for supply chain management. McGraw-Hill/Irwin, New York.

Wheeler, M. S., (2004). Planning for Sustainability, Creating Liveable, Equitable, and Ecological Communities. New York, Routledge

Womack, J.,P., Jones, D.,T., \& Roos, D., (1990). The machine that changed the world. New York: Macmillan Publishing Company.

Yusuf, Y. Y., Angappa, G., Ahmed, M., Mohammed, D., Nagham M. E., \& Shuang C. (2012). A relational study of supply chain agility, competitiveness and business performance in the oil and gas industry. International Journal of Production Economics 145(2), 451-462. 